This item was submitted to Loughborough's Research Repository by the author.

Items in Figshare are protected by copyright, with all rights reserved, unless otherwise indicated.

\title{
The double birth of wireless: Italian radio amateurs and the interpretative flexibility of new media
}

PLEASE CITE THE PUBLISHED VERSION

http://dx.doi.org/10.1080/19376529.2015.1015860

\section{PUBLISHER}

(C) Taylor \& Francis.

\section{VERSION}

AM (Accepted Manuscript)

\section{PUBLISHER STATEMENT}

This work is made available according to the conditions of the Creative Commons Attribution-NonCommercialNoDerivatives 4.0 International (CC BY-NC-ND 4.0) licence. Full details of this licence are available at: https://creativecommons.org/licenses/by-nc-nd/4.0/

\section{LICENCE}

CC BY-NC-ND 4.0

\section{REPOSITORY RECORD}

Balbi, Gabriele, and Simone Natale. 2019. "The Double Birth of Wireless: Italian Radio Amateurs and the Interpretative Flexibility of New Media”. figshare. https://hdl.handle.net/2134/19391. 
This is an Accepted Manuscript of an article to be published by Taylor \& Francis Group in Journal of Radio and Audio Media on 13/01/2015. Suggested citation:

Balbi, Gabriele, and Simone Natale. The Double Birth of Wireless: Italian Radio Amateurs and the Interpretive Flexibility of New Media. Journal of Radio and Audio Media 22, no. 1 (2015, forthcoming).

The Double Birth of Wireless:

Italian Radio Amateurs and the Interpretive Flexibility of New Media

Gabriele Balbi, Università della Svizzera Italiana

Simone Natale, Humboldt University Berlin

\begin{abstract}
This paper argues that the "double-birth" model proposed by Gaudreault and Marion provides a meaningful contribution to our understanding of how wireless telegraphy was developed and eventually re-invented during its early history. Drawing from a case study on the role played by Italian "radio amateurs" between 1900 and the early 1920s, we examine how such users shifted the medium's definition, legislation and identity in the first years after the introduction of wireless technology. The emergence of new potential meanings and applications ultimately rebuilt and redefined this medium, creating space for innovation and multiple "births."
\end{abstract}

\title{
Introduction
}


Since the publication of Carolyn Marvin's When Old Technologies Were New (1988), an expansive body of literature on the history of "new" media proliferated in the field of media studies. As scholars often point out, when a new medium emerges, it passes through a period of "identity crisis" (Gitelman \& Pingree, p. xii) in which its applications and functions are adapted to existing categories of public understanding. In this regard, André Gaudreault and Philippe Marion developed a specific approach to address this issue, which they tentatively baptized the "double-birth model." Through a series of articles published over the course of several years, they proposed the genealogy of a given medium should be regarded as a process in which not one but several different media are created. Media, as Gaudreault and Marion provocatively argue, are always born at least twice: the first time as an extension and continuation of earlier practices; the second when they set out "on a path that enabled the resources it had developed to acquire an institutional legitimacy that acknowledged their specificity" (Gaudreault \& Marion, 2005, p. 4). In its nascence, for instance, cinema replicated the performative and institutional conditions of earlier spectacular forms like theater, magic lantern projections and stage magic (Rossell, 1998, 2014). Only subsequently did cinema establish an identity of its own through a process of stabilization and institutionalization (Gunning, 2000).

While the double-birth model has been applied to cinema, photography and digital media (Gaudreault \& Marion, 2002, 2005, 2013), it has not yet been used to address the history of wireless telegraphy. Yet, perhaps no other medium more adequately exemplifies the dynamics described by Gaudreault and Marion. In fact, when wireless telegraphy was introduced at the end of the nineteenth century, it was conceived, developed and commercially exploited as an extension and perfection of wired telegraphy, allowing point-to-point communication between distant locations. The opportunity to employ wireless telegraphy as a one-to-many medium rose in the following decades, which led to 
the introduction of broadcasting. The early history of wireless (a word in itself with multiple semantic meanings), in this sense, is the history of a double birth: first as an extension of telegraphy, then as a new medium of broadcasting ultimately developing a specific identity of its own.

This article focuses on the analysis of a case study - the role of Italian wireless amateurs in shifting the definition of wireless telegraphy between 1900 and the early 1920 s - to propose that the double-birth model can provide a meaningful contribution to the understanding of how wireless telegraphy was developed, challenged, and eventually re-invented during its early history. It examines how wireless users, the so-called radio amateurs, contributed to changing the definition of this medium, its legislation and identity in the first years after the introduction of wireless technology.

In discussing the case of early Italian wireless telegraphy, the authors have three main objectives. First, they aim to expand discussions on the history of telecommunications by addressing a case study largely overlooked both in Italy and at an international level, as well as also strengthen comparative approaches to the history of wireless communications in different national environments. Second, the authors seek to employ the double-birth model as an interpretative framework to study the historiography of wireless communication, thereby framing the passage of wireless telegraphy to radio broadcasting within wider theories in media history and media archaeology. Finally, this article aims to contribute to the double-birth theory by suggesting a more nuanced approach to the passage from the "first" to the "second" birth of media. Although the shift in the early history of wireless from point-to-point communication to one-tomany forms of communication (which eventually developed in the new medium of broadcasting) seems to confirm Gaudreault and Marion's argument that "media are always born at least twice," 
the case examined by the authors also suggests this theory should be slightly reformulated. Gaudreault and Marion tend to conceive media's second birth as a process of institutionalization or 'constitution' (Gaudreault \& Marion, 2005), responding to a broader tendency within media studies to address the history of media in evolutionary terms (Stöber, 2004). However, the early development of a medium is also characterized by the opening up of new potential applications and uses. As discussed in the next section, it is by examining the emergence of different interpretations and options for the medium's development that one may find the most useful keys for the study and the comprehension of the passage between its first and second birth.

\section{A Model for Media Change: Double Birth and Interpretive Flexibility}

Although the double-birth model's initial application to the case of cinema tended to identify cinema's second birth to the process of its institutionalization - thereby contributing to ongoing debates within film history regarding the distinction between early cinema and so-called classical cinema (Gaudreault, 2004) -, later conceptualizations of this theory proposed a more flexible understanding of the double birth. As Gaudreault and Marion (2013, p. 161) put it, "cinema is indeed a complex phenomenon; and it is necessary to argue for a pluralistic view of its birth/emergence, one that will enable people to see the history of cinema as a succession of beginnings (in the plural) and a succession of deaths (in the plural)." Similarly, in the history of wireless, one may examine emerging interpretations and uses as a reservoir of options that substantiated in the birth of different identities for this medium - and ultimately, in the birth of entirely new media, such as broadcasting. The second birth, in this sense, is a productive process as opposed to a destructive one, wherein new directions and contexts of use for the medium 
emerge. These impending possibilities were often extremely difficult to predict when the medium was invented. Indeed, as the investigation of the case study examined in this article demonstrates, unexpected interpretations of the medium can be strongly influential in directing the early history of a medium towards subsequent "births."

But how can the double-birth theory take into account the role of different interpretations of a new medium as elements that lead to the emergence of such births? In order to answer this question, the authors propose a combination of the double-birth model and elements of the theoretically and methodologically sophisticated Social Construction of Technology (SCOT) model. Within this framework, the concept of interpretive flexibility (Pinch \& Bijker, 1984; Bijker, 1995) points to the existence of a phase in which recently introduced technologies are open to different interpretations and potential use. The notion therefore suggests that, during the early history of a medium, different interpretations of its use are created as imaginative possibilities that concur to establish its potential meaning and applications. According to the SCOT framework, the phase of interpretive flexibility comes to an end when one or more specific uses overcome other possibilities. The end of the interpretive phase, which in the vocabulary of the SCOT is termed the 'closure of flexibility,' can be fruitfully associated to what Gaudreault and Marion call the 'second birth.' In fact, the double-birth model's refusal to take up an evolutionary understanding of media change may even add further nuances to the idea of the closure of flexibility: this can therefore be regarded as a constructive process, by which different interpretations do not compete with each other, but rather concur to the establishment of new identities and births for the new medium.

In the authors' research, by examining the passage from the first to the second birth of 
wireless as a phase of interpretive flexibility, three different interpretations of the new medium of wireless are considered: 1) the legislators' perspective and incentive to protect not only communication but also the wireless flow of electricity; 2) the users' practice of utilizing wireless for receiving information instead of exchanging messages; 3) the judiciary perspective and its reinterpretation of the law taking into consideration the one-to-many application of the medium. The authors would like to emphasize that the passage from the first to the second birth entails the emergence of new ways to regulate, use and imagine the new medium. By examining the case of early Italian radio amateurs, this article will illustrate how the development of new meanings and applications ultimately rebuilt the medium of wireless, opening the space for innovation and multiple "births."

\section{The Flexibility of Wireless and the Italian Specificity}

In the imagination of its inventors and early promoters, wireless telegraphy was a point-to-point medium. It addressed two shortcomings of its predecessor, the electrical telegraph. First, it eliminated the most expensive component of telegraphic networks (wires and cables), and second, it enabled communication in motion while electric telegraphy allowed messages to be exchanged only between two fixed points in space (see, for example, Fahie, 1901; Broca, 1904). As was the case elsewhere, however, in Italy (Galassi, 1903, p. 1) wireless telegraphy also had certain characteristics that were identified by many as key problems. Every person equipped with a wireless set could receive and listen to messages exchanged privately, and they could also interfere with these communications and render them incomprehensible (Walker, 2001; Hong, 2001) As a consequence, the wireless telegraph lacked two fundamental characters of telecommunications: 
secrecy and reliability. Nonetheless, these weaknesses did not limit the commercial and practical success of wireless as a means of communication. Between 1900 and the early 1920s, the new medium proved especially useful in three main fields: the commercial field, for enabling communication related to transport (especially between ships and land stations); the military field, in order to coordinate ships and, later, planes (for example during the Boer Wars and the First World War); and the geopolitical field, for establishing communication between colonies and colonial powers (Balbi 2012a).

As it is often the case with new media (see Rossell, 1998; Thorburn \& Jenkins, 2003; Gitelman \& Pingree, 2003), early wireless also brought with it a degree of 'interpretative flexibility' - a coexistence of alternative meanings and visions regarding what wireless was and that for which it should be used. Among these was the one-to-many use, which later facilitated the emergence of broadcasting. Rather than regarding it as a personal and point-to-point medium, this vision conceived the wireless telegraph as a tool to transmit information and entertainment to a potentially wide, distributed audience. The technology itself did not change, yet this alternative vision addressed the aforementioned weaknesses (especially the lack of secrecy) as strength, i.e. everyone equipped with a radio now possessed a machine with entertaining, informative potential.

In the Italian case, the one-to-many idea of wireless became linked with another way in which the technology was re-imagined as a tool for electrical power transmission without wires. The point to do away with expensive networks of electrical power cables appeared to be an effective option supported by prominent physicists and entrepreneurs like Nikola Tesla (Carlson, 2013; Thibault, 2013). Wireless transmission of electricity in Italy was coupled with that of one-to-many wireless (later called broadcasting). As the authors will proceed to illustrate, this was mainly due to the ways 
in which the wireless flow of electricity was regulated by Italian legislation, and how legislation influenced the use of wireless telegraphy by amateurs in one-to-many terms. The Italian case, therefore, is particularly relevant because a kind of convergent difference emerged in the agency of the legislators and the users. Even if they had different aims (point-to-point transmission of electricity and the receiving of information based one-to-many transmission) they both helped construct new configurations of wireless technology.

In the examination of this neglected case, three primary sources were revealed: 1) the Italian Parliament debates, the Italian Navy Historical Office (INHO), and the construction of laws - all of which help to better understand how politicians understood and regulated wireless; 2) a popular journal of the time edited by the Post and Telegraph Ministry (Rivista delle Comunicazioni) where trials against wireless amateurs were reported; 3) handbooks and juridical books in which law experts commented on the litigation and trials emerging from shortcomings and unexpected consequences of the Italian legislation on wireless. By utilizing such a wide range of different sources, the authors aim to unveil the different institutional and individual roles in the multiple-birth process of wireless.

If political and legislative history is considered in works documenting the history of wireless and broadcasting, linking this dimension with that of users and jurisprudence provides new insight. The Italian case adds strength to the crucial role played by amateurs in developing new ideas, applications (Douglas, 1989; Hoar, 2012; Hendy, 2013) and, specifically, the one-to-many manner of communication. Media historians in different countries often claim that one-to-many wireless became increasingly widespread after the First World War (see for example Briggs, 1961; Walter, 1969; Friedewald, 2000), while this article indicates the idea had emerged strongly already in the 1910s. Furthermore, Italian radio amateurs have been neglected as historical subjects. Italian scholars 
implied that at the start of the twentieth century there were virtually no radio amateurs in Italy (Papa, 1978, chapter 1; Ortoleva, 1984; Monteleone, 1992).

\section{Legislation: Wireless Transmission of Energy}

The early history of a medium involves the creation of particular affordances (i.e. the range of possible actions and functions performed by and with the medium) and the history of how these affordances are overcome (Lister et al., 2009). The limits often replicate the institutional boundaries of existing media and practices. In the case of wireless telegraphy, for instance, they derived largely from the institutional, commercial, and legislative frameworks which characterized the medium (Starr, 2004). The emergence of new interpretations and uses of a medium necessitate the surpassing of limits and affordances established after the medium was introduced (in other words, after its first birth). This often happens when the established situation is challenged by unexpected events or consequences that force those involved to call into question existing interpretations. Because it is precisely within such limits that space for change emerges, studying the nature and character of these affordances and how they are overcome allows a more coherent understanding of how a medium reaches its second or subsequent birth. When the legislative framework in the case examined here was challenged by the unforeseen behavior of a group of social actors - namely radio amateurs - the development of new, competitive definitions of the medium flourished.

When wireless telegraphy was first launched in early-twentieth-century Italy, it prompted debates as to how it should be managed and regulated (Tomlinson, 1945; Headrick, 1991; Hugill, 1999). The creation of laws and rules concerning the new medium contributed to form the affordances limiting the interpretation and use of the new medium. Legislation adopted in Italy in 
1910 extended practically all of the same directives applied to wired telegraphy to the wireless counterpart. Wireless telegraphy in Italy was made a state monopoly for five main reasons: 1) it represented a crucial means of "national defense"; 2) it was inherently a "public service"; 3) it was important for establishing "international relations"; 4) the public monopoly gave grants to private companies according to a central and strategic plan; and 5) wireless transmissions could interfere and overlap, again meaning that public and central control was indispensable (Meloni, 1914, p. 804). For similar reasons, wireless technology was declared a state or state-controlled monopoly in many other countries. Italian legislation on wireless telegraphy contained, among other aspects, a peculiar directive. In establishing the state monopoly, the Italian government not only included the current applications but also other possible uses of wireless, decreeing that the public monopoly should encompass wireless telegraphy, telephone, and every device in which electrical "energy is employed in order to obtain remote effects without the use of wires" (Law no. 395, 30 ${ }^{\text {th }}$ June 1910: article 1). This made sense at a time when, as previously mentioned, a variety of functions were proposed for wireless and, in Italy as elsewhere, the drafting of broad new laws was also driven by the new potential afforded by wireless transmission of electricity. Thus, the laws contemplated and protected a state monopoly over a hypothetical industry that had not yet been realized. What is interesting, however, is that the unintended consequences of these laws could be seen in the use of wireless by Italian radio amateurs and, ultimately, in the development of new definitions for the medium. The affordances embedded in the Italian legislation regulating wireless, in this sense, already contained a degree of flexibility and the potential for innovation to emerge.

The Italian law on wireless established that the Italian government could revoke, suspend, or nationalize wireless grants at any time. Moreover, the use of wireless was strictly regulated and, 
during the debate of the 1910 wireless law, politicians protested against what they deemed exaggerated restrictions imposed on wireless amateurs (Parliamentary debates, May $4^{\text {th }}$ and $5^{\text {th }}, 1910$, pp. 6611 and 6641). Private citizens wishing to experiment with the new technology had to obtain a special license from the Post Ministry. Unauthorized use could be punished by a substantial fine, even up to one year of detention (SITI, without date, p. 58; Meloni, 1914, p. 805). The situation of radio amateurs in Italy mirrored the restrictive regulations that had been created throughout the world. During the first two decades of the twentieth century, radio amateurs were regarded as sources of potential disruption and confusion in the rational organization of wireless worldwide (DeSoto, 1936, p. 70; Dalton, 1975; Bartlett, 2007).

When the First World War broke out, the problem of wireless and public safety was confronted worldwide. Even the content of amateur communications was regulated (Lloyd McQuiggin, 2001, p. 57). The Italian military warned against using wireless in war, a field in which privacy was crucial (Sacco, 1914) and though Italy only joined the conflict in 1915, in 1914 the Italian government suspended all licenses to set up and run wireless stations given to private citizens and companies. There existed a general belief that wireless interested only a very limited proportion of citizens, mainly experimenters, and that the greatest commercial value in the system belonged to the Marconi Company and commercial communications between ships and shore. The Marconi Company was indeed dominant in Italy during the 1900s and 1910s (Giannetto, 1995; Paoloni, 2006; Cavina, 2009; Balbi, 2012b).

The need to adopt wartime measures in 1914 was also due to the fact that wireless had stimulated the interest of Italians to an extent that surpassed the expectations of legislators. Amateurs eager to experiment established private stations without the required authorization. In order to 
prevent private citizens from using wireless sets, the Italian government was forced not only to revoke licenses, but also to uncover and shut down multiple unauthorized wireless stations dispersed throughout Italy (Meloni, 1914, p. 893). As explained in the next two sections, however, the existing legislation - which was linked to particular interpretations of the new medium's uses and functions, such as the possibility to transmit electricity - included certain gaps that facilitated the emergence of different and substantially new interpretations of wireless, such as the ones that conceived it as a one-to-many medium.

\section{Amateurs: Receiving-Without-Transmitting Wireless}

During 1914 and 1915, dozens of people were reported and prosecuted by the Italian Ministry of Post and Telegraphy following the discovery of wireless sets in their homes, though most were eventually set free for various reasons. Some wireless sets were so rudimentary that in many cases they were unable to function (Giannini, 1915), while others were only intended for teaching purposes as opposed to commercial use, and thereby permitted by law. Professors of physics at Italian universities used unassembled wireless equipment for experiments and for teaching electrical communications to their students. As explained in a series of articles in the "Rivista delle comunicazioni," charges against these professors were dropped because:

One cannot speak of a radiotelegraph installation if the various elements are not related to each other and the apparatus cannot be used either for reception or for transmission. The simple presence of the antenna, without a receiver, cannot be considered an installation [of a wireless set]. (Radiotelegrafia - Impianto - Condizioni necessarie, 
1915, p. 163, emphasis added)

Another group of court judgments absolved people found in possession of home wireless sets if they were able to receive but not transmit messages, or, in one case, to transmit and not receive messages. These decisions were directly linked to the Article 1 of Law no. 395 - in particular, its reference to a "remote effect":

The state monopoly on wireless telegraphy and telephony concerns transmission and receiving stations [...]. [T] he mentioned devices neither use electricity nor produce effects at a distance, not being able to transmit signals and dispatches over distance [...]. Criminal charges attributed to Battigelli do not constitute an offense and, consequently, the seized items must be returned to him (Radio-telegrafia - Impianto abusivo Monopolio di Stato, 1915, pp. 162-163, emphasis added).

In other words, many amateurs had set up wireless sets that were able to receive communications, but were unable to transmit (information or, according to the law, energy). And this - according to the Law no. 395, 30th June 1910 - was not punishable.

\section{Jurisprudence: Interpreting the Theft of Energy and the Wireless Itself}

A long series of debates among legal practitioners and law scholars originated from these cases, among others. Debates focused primarily on two aspects: what it meant to "steal" energy and what, exactly, defined wireless telegraphy. Both issues proved relevant in comprehending why this 
"unexpected" reinterpretation of the law by amateurs could not be punished.

As noted, one of the greatest weaknesses of Marconi's wireless telegraphy was the fact that everyone equipped with a set could pick up messages intended for private exchange. Since the mainstream use of wireless was point-to-point, listening-only amateurs were mainly receiving confidential messages exchanged between two strangers. Lawyers, therefore, considered this grounds for the legislative punishment of people who "stole" private messages. The largest obstacle was found in the possibility that:

[...] radio waves directed to the state (could be) received with private equipment, and here is an elegant question, which can fit into the no less elegant but older (question), namely that of the "theft of electricity." (Viola, 1912, p. 77)

Intercepting radio waves sent and directed to other people could hardly be punished. It could not be considered real theft because the electricity used in the Marconi apparatus was used only to transmit dispatches, and therefore intercepting messages could not be interpreted as desire for profit. It was not fraud because it lacked the intention "to deceive or abuse the good faith of others, successfully and owing to the personal act of those who misled" (Viola, 1912, p. 78). It could not be considered a crime against the inviolability of secrets because, at the time, the law "explicitly referred to specific means of correspondence (sealed letter, telegram, lettersheet)" (p. 78) and wireless messages were not sent through wires or in a sealed envelope. In addition, radio amateurs would often pick up messages unintentionally. It was a common experience that, when trying to tune a set, an amateur would encounter the sudden-"popping up” of messages in earphones. Article 315 of the Italian penal 
code was similarly inapplicable to wireless. This article was for the protection of means of transportation and communication and was "applicable in the case of damage to the machines and appliances, or leakage, interruption of current in transmitters and receivers, as well as when interposed devices [...] (prevent the) dispatch from reaching its destination" (p. 79). Nevertheless, in the case of wireless, "radio waves regularly reach their destination, but interposed devices have already obtained their secrets" (p. 79). In other words, even if wireless messages were picked up by unintended recipients, the delivering of the messages was not obstructed. This is a key characteristic of "public goods" (like broadcasting, see Scannell, 1989), namely goods that, once produced, can be consumed by everyone because "the way [a public good] is consumed by any individual [...] does not reduce its supply for everyone else. The essential quality [...] is not physical. Instead, it is in the meanings or messages conveyed" (Doyle, 2002, p. 61). In summary, picking up wireless messages could not be punished under Italian law, which intensified the problem related to wireless waves' inherent lack of direction and consequent secrecy. The lack of secrecy, however, could also be seen as an opportunity. In fact, as Lars Nyre observes (2008), the opportunity to listen to private communications, coupled with the possibility to exchange communications, encouraged the spread of wireless sets, wireless experimentation, and more in general of a "sense of shared fascination" for wireless (p. 170).

A further element that facilitated the proliferation of new interpretations was the debate on wireless legislation and, more generally, wireless telegraphy itself. Regarding Italian legislation on wireless, commentators claimed that, "in 1910 we were in [such] a hurry to foresee the future in order to preserve a monopoly not only for radiotelegraph and radiotelephone stations, but also for any other long distance transmission of electricity without wires" (Giannini, 1915, pp. 133-138). The 
government should have restructured the law, regulating wireless telegraphy and telephony differently from the transmission of energy, since their joint regulation resulted in confusion. Two of the most relevant reasons to establish a state monopoly were to avoid radio interference and to maintain control over (and protection of) wireless messages. Amateur radio practices such as picking up and listening in endangered both:

Receiving contributes indirectly to interfering with the transmission of other messages, it damages the income tax, it spreads public and private secrets, or it gives for free information and services (such as time signals, weather, etc.) that in general you have to pay for. (Giannini, 1915, pp. 137-138)

Yet, judges interpreted the law such that receiving without transmitting did not constitute an infringement on the public monopoly, simply because it was neither telegraphy nor telephony. In order to telecommunicate, in fact, there had to be a proper, interactive dialogue between sender and receiver of information. Drawing on this interpretation of the law, Italian radio amateurs identified with the overly generic drafting of their national legislation and benefited from it, creating a completely new understanding of wireless, which differed markedly from point-to-point telecommunications and established certain patterns that would characterize broadcasting. The amateurs transformed, becoming not so much wireless telegraph/telephone users but something akin to radio audiences avant la lettre (the medium had not been invented yet). In this way, they were not punishable by the new law. The aforementioned trials saw the conflict between two ideas of communication: the point-to-point function of wireless as a tool to transmit and receive in interactive 
ways without physical connections; and the one-to-many function as a tool that allowed listeners to pick up discussions, signals and messages exchanged by others or to listen to common content transmitted over the air at the time (for a discussion of this dichotomy, see Peters, 1999, pp. 36-62; Lindqvist, 2011, p. 234; Balbi \& Kittler, 2012). Italian legislation considered and protected only the mainstream use of wireless, which was point-to-point communication, and courts found amateurs who used their tools differently not guilty of committing offense. They were simply doing something different, something that ultimately resulted in the "second birth" of wireless and the evolution of the medium's definition.

\section{Not a Brand New Idea: The 'Circular' Listening}

Radio amateurs did not invent any new concept, they simply took and adapted to their needs an idea that was literally 'on the air' with wireless telegraphy: the so called circular transmissions. It was an alternate way of looking at the new technology since its inception. Early examples of wireless used in one-to-many transmissions include the SOS distress signals sent from ship to ship and shore stations, time and weather forecasts sent from land stations to ships, and newspaper receivers picking up news over the air (Burrows, 1924, p. 3).

In Italy, the idea of listening to common content transmitted from a central radio station to multiple listeners emerged in two ways before the First World War. First, certain institutions and individuals were interested in receiving (or rather, picking up) specific content over the air. For example, astronomical observatories were interested in receiving time signals and weather forecasts sent from the Eiffel Tower at a given time on a precise schedule to test their apparatus (Aitken, 1985, p. 190) and to synchronize themselves - this reminds also the concept of "despatialised simultaneity" 
described by John B. Thompson (1995, p. 32) as one of the key features of broadcasting. Among these Italian observatories, two - the Osservatorio Ximeniano in Florence and the Osservatorio of Moncalieri near Turin - were led by Father Guido Alfani and Father Dionigi Boddaert, both clergymen and experts on wireless in Italy (Alfani, 1912; Boddaert, 1913). Italian ships were interested in receiving news bulletins (and later full newspapers) in order to keep up with current events (Guarini, 1900, p. 24). Listening to messages, content and whatever else was passed over the airwaves became a worldwide hobby after the Eiffel Tower set up a daily news service in the early 1910s (Mazzotto, 1912, p. 524; Giannini, 1920, p. 12). Even before the First World War, the Italian Navy transmitted an official news bulletin using wireless technology (INHO, 1913). The involvement of amateurs in circular transmission, however, radically changed the context of its use, as users were able to engage in wireless communication for information and entertainment purposes.

Second, early experimentation unfolded in Italy by way of listening to one-to-many transmissions conducted in real time with technology like the telephone, or rather the 'circular telephone,' as it was referred to at the time. Between the late nineteenth century and the first two decades of the twentieth, the telephone was used not only as a point-to-point medium, but also as a one-to-many medium in France, the United Kingdom, Hungary, the United States of America and Italy, among other countries. In Italy, the circular telephone was called Araldo Telefonico (the Telephone Herald), and appeared in Rome in the early 1910s. Through special telephones in homes and public clubs, subscribers could receive a diverse schedule of educational, informational and entertaining programs. This interweaving of genres, structures and ideas would later structure radio broadcasting (Balbi, 2010).

The existence of such markedly different environments in which ideas of 'listening in' or 
circular listening were developed and put into use suggests that new interpretations and meanings concurring to a medium's second or subsequent birth may emerge in a broad range of cultural, social, and economic contexts. In this sense, as the authors have argued elsewhere (Natale \& Balbi, 2014, pp. 208-209), the condition of interpretive flexibility in a medium's infancy can be compared to a kind of brainstorming, by which the availability of diverse interpretations and potential meanings facilitate the creation of a pool of ideas that are animated and put into use by the social actors involved in the medium's early history.

\section{Conclusion}

The gaps in Italian legislation, the willingness of amateurs to receive messages without transmitting them, the court decisions and reinterpretation of laws that acknowledged the alternative idea of wireless made by users, and finally the old idea of circular listening through airwaves and the telephone changed the meanings of wireless itself. All these processes were linked and, before the First World War, synthesized to establish an alternative, one-to-many concept of wireless communication as opposed to merely point-to-point.

By examining the confluence of different agencies and social actors in the emergence of new interpretation and utilization of the wireless medium, this article contributes a layer of depth to the history of telecommunications in addition to the double-birth theory. The case of Italian radio amateurs helps add further complexity and analytical depth to the double-birth model, proposing an understanding of the passage to different and subsequent births based on the concept of interpretative flexibility derived from the SCOT theory. Reexamining the double-birth model in light of cinema's recent history in the digital age, Gaudreault and Marion (2013) acknowledge that 
one should conceive media change as a process by which media are constantly recreated in a sequence of multiple, rather than double, births. In order to understand how established affordances are challenged and new visions and applications of media emerge, however, researchers need to go beyond this view to conceive a medium's second (or multiple) birth as something that opens - rather than closes - the spectrum of potential use. Throughout history, media evolve and demand new conceptualization along with the expansion of pre-established limits in ways that are difficult (if not impossible) to forecast (Natale \& Balbi 2014; Natale 2014). In so doing, they rarely replace former definitions and uses - to the contrary, they add to them. Regarding wireless technology, the emergence of new applications based on the one-to-many communication model did not substitute, but rather coexisted with the technology's use as a pointto-point communication medium. In fact, wireless 1.0 and wireless 2.0 (first and second births) have lived and are still living together, as broadcasting and mobile phone demonstrate today. Indeed, the point-to-point paradigm of wireless communications has stimulated reflections on broadcasting too: so the second birth was confronted with the first one in a kind of retrospection. Thus, in the 1930s, when broadcasting was a new medium, German writer Berthold Brecht (1993) called for a return to reciprocity in radio communications, hinting at the medium's origins as a point-to-point medium: "Radio is one sided when it should be two. It is purely an apparatus for distribution, for mere sharing out" (p. 15). At this point, Brecht proposes, "So here is a positive suggestion: change this apparatus over from distribution to communication. The radio would be the finest possible communication apparatus in public life, a vast network of pipes." Concluding, he adds, "That is to say, it would be if it knew how to receive as well as to transmit, how to let the listener speak as well as hear, how to bring him into a relationship instead of isolating him" 
(Brecht, 1993, p. 15).

This broadening of applications and meanings, characterized as a second birth, entails the redefining of a space that is constructive as opposed to destructive in essence. To paraphrase Gaudreault and Marion, the authors' discussion of the Italian radio amateur case suggests a medium is born not just once but many times as new interpretations, definitions and uses emerge. In examining these subsequent births, one obtains a deeper understanding of the complex evolution of media throughout time. It is precisely this understanding that allows scholars to comprehend the inherently dynamic nature of media history, as new media constantly emerge while older media are redefined and recreated again and again (Balbi, 2015). 


\section{References}

Aitken, H. G. J. (1985). The continuous wave: Technology and American radio, 1900-1932. Princeton: Princeton University Press.

Alfani, G. (1912). L'Osservatorio ximeniano e il suo materiale scientifico: $V$ (la stazione radiotelegrafica). Florence: Tip. S. Giuseppe.

Balbi, G., \& Kittler, J. (2012). Dialoguing with Socrates or disseminating like Jesus? Rereading communication history through 'one-to-one' and 'one-to-many' lenses. Paper presented at ICA (International Communication Association) Conference, Phoenix, AZ, May 2012.

Balbi, G. (2010). Radio before radio: Araldo Telefonico and the invention of Italian broadcasting. Technology and Culture, 51(4), 786-808.

Balbi, G. (2012a). Telecommunications. In P. Simonson, J. Peck, R. T. Craig, \& J. P. Jackson (Eds.), Handbook of Communication History (pp. 209-222). New York, NY: Routledge.

Balbi, G. (2012b). Marconi's diktats. How Italian international wireless policy was shaped by a private company, 1903-1911. HISTELCON (History of Electro-technology Conference), Pavia, September. Retrieved from http://ieeexplore.ieee.org/xpl/login.jsp?tp=\&arnumber=6487559\&url=http\%3A\%2F\%2Fiee explore.iee.org\%2Fiel7\%2F6480931\%2F6487554\%2F06487559.pdf\%3Farnumber\%3D6 487559).

Balbi, G. (2015). Old and new media: Theorizing their relationships in media historiography. In S. Kinnebrock, C. Schwarzenegger, \& T. Birkner (Eds.), Theorien des Medienwandels (pp. 240258). Köln: Halem.

Bartlett, R.A. (2007). The world of ham radio, 1901-1950: a social history. Jefferson, NC: 
McFarland \& Company.

Bijker, W. E. (1995). Of bicycles, bakelites, and bulbs: Toward a theory of sociotechnical change. Cambridge, MA: MIT Press.

Boddaert, D. (1913). L'impianto radiotelegrafico dell'osservatorio di Moncalieri. Turin: Tip. Collegio Artigianelli.

Briggs, A. (1961). The history of broadcasting in the United Kingdom. Vol. 1, The Birth of Broadcasting, 1896-1927. Oxford, UK; New York, NY: Oxford University Press.

Brecht, B. (1993). The radio as an apparatus of communication. In N. Strauss (Ed.), Radiotext[e] (pp. 15-17). New York: Semiotext[e]. Original source: Brecht, B. (1932). Der Rundfunk als Kommunikationsapparat. Blätter des Hessischen Landestheaters, Darmstadt, 16, July.

Broca, A. (1904). La telélegraphie sans fils. Paris: Gauthier-Villars.

Browne, D. R. (1989). Comparing broadcast systems: The experiences of six industrialized nations. Ames, IA: Iowa State University Press.

Burrows, A. R. (1924). The Story of Broadcasting. London: Cassell and Company.

Carlson W. B. (2013). Tesla: Inventor of the electrical age. Princeton, NJ: Princeton University Press.

Cavina, U. (2009). La telegrafia senza fili e il suo sviluppo in Italia. Albino: Sandit libri.

Dalton, W. M. (1975). The story of radio. Bath: Hilger.

DeSoto, C. B. (1936). Two hundred meters and down. West Hartford, CT: American Radio Relay League.

Douglas, S. J. (1989). Inventing American broadcasting, 1899-1922. Baltimore, MD: Johns Hopkins University Press. 
Doyle, G. (2002). Understanding media economics. London: SAGE.

Eko, L. S. (2012). New media, old regimes: Case studies in comparative communication law and policy. Lanham, MD: Lexington Books.

Fahie, J. J. (1901). A history of wireless telegraphy: Including some bare-wire proposals for subaqueous telegraphs. Edinburgh: Blackwood.

Fischer, C. S. (1992). America calling: A social history of the telephone to 1940. Berkeley, CA: University of California Press.

Friedewald, M. (2000). The beginnings of radio communication in Germany, 1897-1918. Journal of Radio Studies, 7(2), 441-462.

Galassi, M. (1903). La telegrafia senza fili e il Codice Penale. Torino: Stamperia dell'Unione Tipografico-Editrice.

Gaudreault, A., \& Marion, P. (2002). The cinema as a model for the genealogy of media. Convergence: The International Journal of Research into New Media Technologies, 8(4), $12-18$.

Gaudreault, A., \& Marion, P. (2005). A medium is always born twice. Early Popular Visual Culture, $3(1), 3-15$.

Gaudreault, A., \& Marion, P. (2013). Measuring the 'double birth' model against the digital age. Early Popular Visual Culture, 11(2), 158-177.

Gaudreault, A. (2004). Il cinema delle origini o della cinematografia-attrazione. Milano: Il Castoro.

Giannetto, M. (1995). Marconi e l'amministrazione italiana. In G. Paoloni e F. Monteleone (a cura di), Cento anni di radio: da Marconi al futuro delle telecomunicazioni, Venice: Marsilio.

Giannini, T. C. (1915). Gli impianti radiotelegrafici abusivi davanti alla giustizia penale. Rivista 
delle comunicazioni, pp. 133-138.

Giannini, T. C. (1920). La radiotelegrafia nell'economia e nella legislazione. Roma: Agenzia Radiotelegrafica Italiana.

Gitelman, L., \& Pingree, G. B. (2003). New media, 1740-1915. Cambridge, MA: MIT Press.

Guarini, E. (1900). La telegrafia senza fili e la canalizzazione dell'elettricità senza fili. Conferenza fatta in Roma il 29 giugno 1900 nel salone dell'Associazione artistica internazionale. Rome: Tipografia Nazionale di G. Berterio.

Gunning, T. (2000). The cinema of attraction: Early cinema, its spectator, and the avant-garde. In R. Stam \& T. Miller (Eds.), Film and Theory: An Anthology (pp. 229-235). Malden: Blackwell. Headrick, D. R. (1991). The invisible weapon: Telecommunications and international politics, 1851 1945, New York: Oxford University Press.

Hendy, D. (2013). The dreadful world of Edwardian wireless. In S. Nicholas \& T. O’Malley (Eds.), The media, social fears and moral panics: Historical perspectives (pp. 76-89). New York, NY: Routledge.

Hesmondhalgh, D. (2002). The cultural industries. London: Sage.

Hoar, P. (2012). Morse, magic and modernity: Receiving radio in New Zealand, 1900-1914. In M. Mollgaard (Ed.), Radio and society: new thinking for an old medium (pp. 1-15). Newcastleupon-Tyne: Cambridge Scholars.

Hong, S. (2001). Wireless: from Marconi's black-box to the audion. Cambridge, MA: MIT Press.

Hugill, P. J. (1999). Global communications since 1844: Geopolitics and technology, Baltimore, MD: Johns Hopkins University Press.

INHO, Italian Navy Historical Office. (1913). Folder 302, no. 3. 
John, R. R. (2010). Network nation: Inventing American telecommunications. Cambridge, MA: Belknap Press of Harvard University Press.

Katsh, M. E. (1989). The electronic media and the transformation of law. New York, NY: Oxford University Press.

Lindqvist, S. (2011). Changes in the technological landscape: Essays in the history of science and technology. Sagamore Beach, MA: Science History Publications.

Lister, M. et al. (2009). New media: a critical introduction. 2nd ed. New York, NY: Routledge.

Lloyd McQuiggin, K. W. (2001). Amateur radio and innovation in telecommunications technology. MA Thesis, Simon Fraser University.

Malin, B. J. (2011). Failed transmissions and broken hearts. Media History, 17(4), 331-344.

Mallard, A. (2005). Following the emergence of unpredictable uses? New stakes and tasks for a social scientific understanding of ICT uses. In L. Haddon, E. Mante, B. Sapio, K-H. Kommonen, L. Fortunati, \& A. Kant (Eds.), Everyday innovators: Researching the role of users in shaping ICTs (pp. 39-53). Dordrecht: Springer.

Marvin, C. (1988). When old technologies were new. Thinking about electric communication in the late nineteenth century. New York, NY: Oxford University press.

Mazzotto, D. (1912). Radiotelegrafia e radiotelefonia. 2. ed. interamente riv. ed aumentata. Milano: U. Hoepli.

Meloni, G. (1914). Ragioni e sanzioni della legge sulla radiotelegrafia e radiotelefonia. Milano: Società Editrice Libraria.

Monteleone, F. (1992). Storia della radio e della televisione in Italia. Venice: Marsilio.

Natale, S., \& Balbi, G. (2014) Media and the imaginary in history: The role of the fantastic in 
different stages of media change. Media History, 20(2), 203-18.

Natale, S. (2014). Introduction: New media and the imagination of the future. Wi: Journal of Mobile Media, 8(2), 1-8.

Nye, D. E. (2006). Technology matters. Questions to live with. Cambridge, MA: MIT Press.

Nyre, L. (2008). Sound media. From live journalism to music recording. London: Routledge.

Ortoleva, P. (1984). La radio e il suo pubblico: verso una storia degli ascoltatori. In P. Ortoleva e F. Monteleone (a cura di), La radio storia di sessant'anni 1924/1984. Turin: Rai-ERI.

Oudshoorn, N., \& Pinch, T. J. (Eds.) (2003). How users matter: The co-construction of users and technologies. Cambridge, MA: MIT Press.

Paoloni, G. (2006). Fili, microfoni e antenne: dal telegrafo alle telecomunicazioni. In A. Giuntini e G. Paoloni (a cura di), Le Poste in Italia 2. Nell'età del decollo industriale 1889-1918, RomaBari: Laterza.

Papa, A. (1978). Storia politica della radio in Italia. Dalle origini agli anni della crisi economica, 1924-1934. Naples: Guida.

Peters, J. D. (1999). Speaking into the air: A history of the idea of communication. Chicago, IL: University of Chicago Press.

Pinch, T. J., \& Bijker, W. E. (1984). The social construction of facts and artefacts: Or how the sociology of science and the sociology of technology might benefit each other. Social Studies of Science, 14, 399-441.

Radiotelegrafia - Impianto - Condizioni necessarie. Pretore di Ferrara, 12 marzo 1915 BONGIOVANNI. (1915). Rivista delle comunicazioni, p. 163.

Radio-telegrafia - Impianto abusivo - Monopolio di Stato. Tribunale di Firenze, 2 marzo 1915 - 
BATTIGELLI. (1915). Rivista delle comunicazioni, pp. 162-163.

Ross, A. (1991). Strange weather: Culture, science, and technology in the age of limits. London: Verso.

Rossell, D. (1998). Living pictures: The origins of the movies. Albany: State University of New York Press.

Rossell, D. (2014). Demolition d'un mur: The social construction of technology and early cinema projection systems. Early Popular Visual Culture, 12(3), 304-341.

Sacco, L. (1914) Note sulle applicazioni campali della radiotelegrafia. Rome: Tip. E. Voghera.

Sarat, A., \& Kearns, T. R. (Eds.) (1999). History, memory, and the law. Ann Arbor, MI: University of Michigan Press.

Scannell, P. (1989). Public service broadcasting and modern public life. Media Culture and Society, $11(2), 135-166$.

S.I.T.I. (without date) Societa Industrie Telefoniche Italiane "Doglio". Vade mecum del radioamatore. Milano: S.I.T.I.

Starr, P. (2004). The creation of the media: Political origins of modern communications. New York, NY: Basic Books.

Stöber, R. (2004). What media evolution is. European Journal of Communication, 19(4), 483-505.

Thibault, G. (2013). The automatization of Nikola Tesla: Thinking invention in the late nineteenth century. Configurations, 21(1), 27-52.

Thompson, J. B. (1995). The media and modernity: A social theory of the media. Stanford: Stanford University Press.

Thorburn, D., \& Jenkins, H. (Eds.) (2003). Rethinking media change: The aesthetics of transition. 
Cambridge, MA: MIT Press.

Tomlinson, D. (1945). The international control of radio communications. Ann Arbor, MI: J.W. Edwards.

Viola, P. L. (1912). La telegrafia senza fili e la navigazione aerea nei loro rapporti col diritto Internazionale. Questioni di diritto aereo. Milan: Tip. Figli Della Provvidenza.

Youm, K. (2006). Legal methods in the history of electronic media. In D. Godfrey (Ed.), Methods of historical analysis in electronic media (pp. 115-144). Mahwah, NJ: Lawrence Erlbaum Associates.

Walker, J. (2001). Rebels on the air: An alternative history of radio in America. New York, NY: New York University Press.

Walter, B. E. (1969). National and international systems of broadcasting; Their history, operation, and control. East Lansing, MI: Michigan State University Press. 